\title{
Recent Advancement in Controlling Industrial Pollutions
}

\author{
R. Abinethri, T.Vijayan, B.Kalaiselvi
}

\begin{abstract}
Contaminants convey contamination into the regular habitat that makes unfriendly alternate. contamination can appear as artificial substances or power, for example, commotion, warm temperature or light pollutants. Wind-blown residue and flotsam and jetsam, along with plastic sacks, are blown offshore from landfills and specific zones. Plastic sacks and one-of-a-kind varieties of plastic waste that have been disposed of which exhausted inside the sea, gift dangers to untamed existence and fisheries. finally this paper learns about infection manage in cutting-edge circumstance. [1],[3],[5]
\end{abstract}

Keywords : pollution,airways,control

\section{INTRODUCTION}

In late headways, the development material for little and ease sensors turned out to be in fact and financially practical. Regardless of the way that, Industrialization increase the degree of computerization and meanwhile it assembles the air sullying by releasing the unwanted gasses in condition especially in current ranges.So there should be a system to screen and assess the cutting edge tainting. The terms observing and appraisal are habitually befuddled and utilized synonymously. The procedure of mechanical quality appraisal is an assessment of the modern quality in connection to standard quality set by contamination control board. Specific consideration is given to factors which may influence human wellbeing and the soundness of the normal framework itself. Natural quality appraisal incorporates the utilization of checking to characterize the state of water, to give premise to distinguishing patterns and to give the data empowering the foundation of cause powerful connections. Modern checking is the gathering of data at various areas of businesses and at customary interims of time so as to give the information which might be utilized to characterize current conditions. Because of the intricacy of parameters enormous varieties are found between various businesses. So also, the reaction to mechanical effects is likewise exceptionally factor. Remote Monitoring, Control and keen upkeep is one of the most significant criteria for expanding creation and procedure plant accessibility. The utilization of checking has additionally developed to decide inclines in the nature of the water, air and soil condition and how they are influenced by the arrival of contaminant, and by waste treatment activity. Even more starting late, watching has been grasped to assess supplement or toxin movements discharged to conduits, ground waters, lakes, oceans and soil or across over worldwide the points of

Revised Manuscript Received on August 22, 2019.

R.Abinethri, Department of EIE,Bharath Institute of Higher education and research, Tamilnadu, India. Email: abi.eie@bharathuniv.ac.in

T.Vijayan, Department of EIE,Bharath Institute of Higher education and research, Tamilnadu, India. Email: vijayan.eie@bharathuniv.ac.in

B.Kalaiselvi, Department of EIE,Bharath Institute of Higher education and research, Tamilnadu, India. Email: kalaiselvi.eie@bharathuniv.ac.in confinement. Regardless, it should be seen that mechanical common quality is extraordinarily factor dependent upon neighborhood conditions. Finally it is most use full for present day field [2 ],[4],[6]

\section{Materials AND METHODS}

watching systems are arranged and executed for get-collectively records on enveloping air and water pleasant and on entries of defilements of strain from genuine point assets. The elements of a checking plan typically fuse selection of the parameters of concern; the machine for collection and treatment of exams (demonstrating the vicinity, the repeat, type, and degree of tests, and searching at equipment); test exam (or, adjust domestically, on line looking); and a path of action for asserting the results. Incorporating levels of pollutions, as an instance, sizable metals are expected in air, water, and soil, nearby diverse parameters, at determined areas and frequencies and the use of showed system and systems. The goal is to gather and separate operator tests to carry records to be used in the environmental organization structure. To make certain commendable incorporating stages, combinations of defilements in nature are expected, using fashions and facts on outpourings from a chunk of the vital sullying resources, and are then watched. [7],[ 9], ,[11]

\section{RESULTS}

Mechanical checking is the accumulating of information at special zones of agencies and at regular between instances of time remembering the last goal to provide the statistics which may be used to painting cutting-edge situations. as a consequence of the multifaceted idea of parameters vast assortments are located among distinct ventures. moreover, the reaction to cutting-edge impacts is in like manner notably component. far flung monitoring, manage and canny help is a champion among the maximum simple criteria for reinforcing creation and procedure plant openness. the use of checking has also improved to pick out slants in the concept of the water, air and soil circumstance and how they may be impacted through the access of contaminant, and with the aid of waste remedy pastime. Even more beginning late, checking has been endeavored to assess complement or defilement advances discharged to streams, floor waters, lakes, oceans and soil or transversely over worldwide the cutoff points. Regardless, it should be visible that mechanical environmental nice is rather aspect established upon close by situations. [8],[10],[12] 


\section{Recent Advancement in Controlling Industrial Pollutions}

\section{CONCLUSION}

the sphere of contamination research and manipulate is huge and multiple works has been attempted to restrain the problem of rate and standard checks through the utility of global system for cellular interchanges. For assuaging these issues, superior GSM system may be used. The execution and electricity of the sullying watching and manipulate shape also can be upgraded by means of finishing sensors for controlling residue, clamor, smoke, moistness and diverse parameters, as such improving the current and everyday habitat. [13], [15] ,[ 17]

\section{REFERENCES}

[1] Sharma, R.K., Irusapparajan, G. \& Periyaazhagar, D. 2019, "Three-phase symmetric cascading Z-source seven levels multilevel inverter excited by multi carrier sinusoidal pulse width modulation scheme", International Journal of Innovative Technology and Exploring Engineering, vol. 8, no. 10, pp. 4269-4274.

[2] Velavan, R., Bharanidharan, S. \& Sheeba, B. 2019, "EMF pollution Causes, effects and protection", International Journal of Innovative Technology and Exploring Engineering, vol. 8, no. 9 Special Issue 3, pp. 1166-1168.

[3] Saravana, S., Balaji, S., Arulselvi, S. \& John Paul Praveen, A. 2019 "Reliable power quality monitoring and protection system", International Journal of Innovative Technology and Exploring Engineering, vol. 8, no. 9 Special Issue 3, pp. 644-645.

[4] Tamil Selvan, S. \& Sundararajan, M. 2019, "Performance Parameters of 3 Value 8t Cntfet Based Sram Cell Design Using H-Spice", International Journal of Recent Technology and Engineering, vol. 8, no. 2 Special issue 5, pp. 22-27.

[5] Jac Fredo, A.R., Abilash, R.S., Femi, R., Mythili, A. \& Kumar, C.S 2019, "Classification of damages in composite images using Zernike moments and support vector machines", Composites Part B: Engineering, vol. 168, pp. 77-86

[6] Kathiravan, P. \& Govindaraju, C. 2019, "Design and evaluation of ultra gain isolated DC-DC converter for photovoltaic system", International Journal of Engineering and Advanced Technology, vol. 8, no. 5, pp. 2646-2651.

[7] Kripa, N., Vasuki, R. \& Kishore Kanna, R. 2019, "Realtime neural interface controlled au-pair BIMA bot", International Journal of Recent Technology and Engineering, vol. 8, no. 1, pp. 992-994.

[8] Mohanraj, Meenaa Kumari, M., Philomina, S. \& Jasmin, M. 2019 "In-situ humidity measurement of hydrogen fuel cell car using MEMS sensor", International Journal of Recent Technology and Engineering, vol. 8 , no. 1, pp. 41-43.

[9] Velmurugan, T. \& Prakash, S. 2019, "Artificial intelligent based distribution automation of swift fault detection isolation and power restoration for HT network", International Journal of Innovative Technology and Exploring Engineering, vol. 8, no. 6, pp. 1-6.

[10] Dwarakesh, K. \& Prem Kumar, G. 2019, "Five-level inverter based sequential boost system using fuzzy logic controller", International Journal of Innovative Technology and Exploring Engineering, vol. 8, no. 6, pp. 12-19.

[11] Anne Gifta, A. \& Hemavathi, G. 2019, "Analysis of grid tied solar PV system using ANFIS Algorithm", International Journal of Innovative Technology and Exploring Engineering, vol. 8, no. 6, pp. 312-316.

[12] Jayavel, R., Rangaswamy, T.R. \& Prakash, S. 2019, "Efficient grid management system with renewable and conventional power sources", International Journal of Innovative Technology and Exploring Engineering, vol. 8, no. 6, pp. 287-289.

[13] Hemavathi, G. \& Maheshwaran, S. 2019, "Proportional resonant controlled high gain step-up converter system with improved response", International Journal of Innovative Technology and Exploring Engineering, vol. 8, no. 6, pp. 317-323.

[14] Periyaazhagar, D. \& Irusapparajan, G. 2019, "Design and completion of asymmetric single phase 27 level cascaded mli for various pwm scheme", International Journal of Innovative Technology and Exploring Engineering, vol. 8, no. 6, pp. 792-797.

[15] Mahalakshmi, V. \& Vijayaragavan, S.P. 2019, "PV based power electronic converters for high voltage DC applications", International Journal of Recent Technology and Engineering, vol. 7, no. 6, pp. 670-674.

[16] Irusapparajan, G., Periyaazhagar, D., Prabaharan, N. \& Rini Ann Jerin, A. 2019, "Experimental verification of trinary DC source cascaded h-bridge multilevel inverter using unipolar pulse width modulation", Automatika, vol. 60, no. 1, pp. 19-27.

[17] Sangeetha, G., Sherine, S., Arputharaju, K. \& Prakash, S. 2019, "On Line Monitoring of Higher Rated Alternator using Automated Generator Capability Curve Administer", Proceedings of the IEEE International Conference on \&amp;quot;Recent Trends in Electrical, Control and Communication\&amp;quot;, RTECC 2018, pp. 176

[18] Bycil, V.J. \& Wiselin, M.C.J. 2019, "Modeling and analysis of vibration energy harvesting system using piezo stack", International Journal of Mechanical and Production Engineering Research and Development, vol. 9, no. Special Issue 1, pp. 523-533.

[19] Sripada, A., Warrier, A., Kapoor, A., Gaur, H. \& Hemalatha, B. 2018 "Dynamic lateral balance of humanoid robots on unstable surfaces", International Conference on Electrical, Electronics, Communication Computer Technologies and Optimization Techniques, ICEECCOT 2017, pp. 539

[20] Srinivasan, S., Thirumalaivasan, K. \& Sivakumaran, T.S. 2018, "Performance evaluation of double-output luo converters", Journal of Advanced Research in Dynamical and Control Systems, vol. 10, no. 10 Special Issue, pp. 870-878.

[21] Karthikayen, A. \& Selvakumar Raja, S. 2018, "A skellam distribution inspired trust factor-based selfish node detection technique in MANETs", Journal of Advanced Research in Dynamical and Control Systems, vol. 10, no. 13, pp. 940-949.

\section{AUTHORS PROFILE}

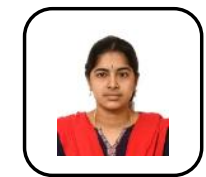

R.Abinethri, Assistant Professor, Department of EIE,Bharath Institute of Higher education and research, Tamilnadu, India

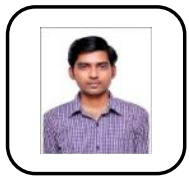

T.Vijayan, Assistant Professor, Department of EIE,Bharath Institute of Higher education and research, Tamilnadu, India

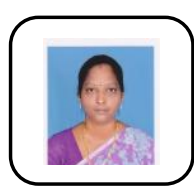

B.Kalaiselvi, Assistant Professor, Department of EIE,Bharath Institute of Higher education and research, Tamilnadu, India 